Annals of Warsaw University of Life Sciences - SGGW

Land Reclamation No 40, 2008: 27-37

(Ann. Warsaw Univ. of Life Sci. - SGGW, Land Reclam. 40, 2008)

\title{
The impact of land use on the water quality of foothill microcatchment areas
}

\author{
ANDRZEJ MISZTAL, MARCIN KUCZERA \\ University of Agriculture in Cracow \\ Department of Ecological Bases of Environmental Engineering
}

\begin{abstract}
The impact of land use on the water quality of foothill microcatchment areas. In this paper a comparison is made between the impact of land use methods on the quality of water in the streams which drain various catchment areas. For this purpose three microcatchments were selected which are located in agricultural, rural settlements, and forested areas. Water samples were physically and chemically analysed in order to determine: nitrates, nitrites, ammonia, phosphates, sulphates, chlorides, calcium, magnesium, dissolved oxygen, reaction and conductivity. The above studies were conducted in the 2006 and 2007. Our analysis of the collected materials allows us to affirm that land use methods have a significant impact on the water quality of the streams which drain the area. Rural settlement has the most negative influence on the water quality, followed by typical agricultural use. Based on the direct quality evaluations of single water samples, it has been found that only water from forested areas can be qualified as belonging to the 1 st cleanness class.
\end{abstract}

Key words: land use, foothill microcatchments, water quality.

\section{INTRODUCTION}

In spite of the important functions which small water streams fulfil in the environment, they are exposed to many negative factors, mainly of anthropogenic origin. Rising living standards as well as increasing urbanisation have become the reasons for significant, not always favourable, impact of humans on the natural environment. Protecting water resource quality from pollution is one of the main problems of contemporary civilisation. The objective of this paper is to compare the quality of water flowing from foothill microcatchment areas where the land is used in various ways.

\section{MATERIAL AND METHODS}

In the work a collation has been made of the impact of land use methods on the water quality of small streams. For this purpose three streams were chosen which drain the agriculturally used land, rural settlements and forested areas, and from which water samples were subjected to physical-chemical analyses which determined 11 quality indicators. The investigated research sites are located in the Malopolska region, in the district of Bochnia (Bochnia and Nowy Wiśnicz communes) and in the district of Brzesko (Brzesko commune) situated within two meso-regions, e.g. the Bocheński and Wiśnicki Foothills (Kondracki 2002) (Fig. 1). The distribution of gradients of agriculturally used catchment area revealed that the terrain $(81.56 \%)$ was dominated by the slopes in range from 0 to $10 \%$. Predominant part of the catchment area is occupied by arable 


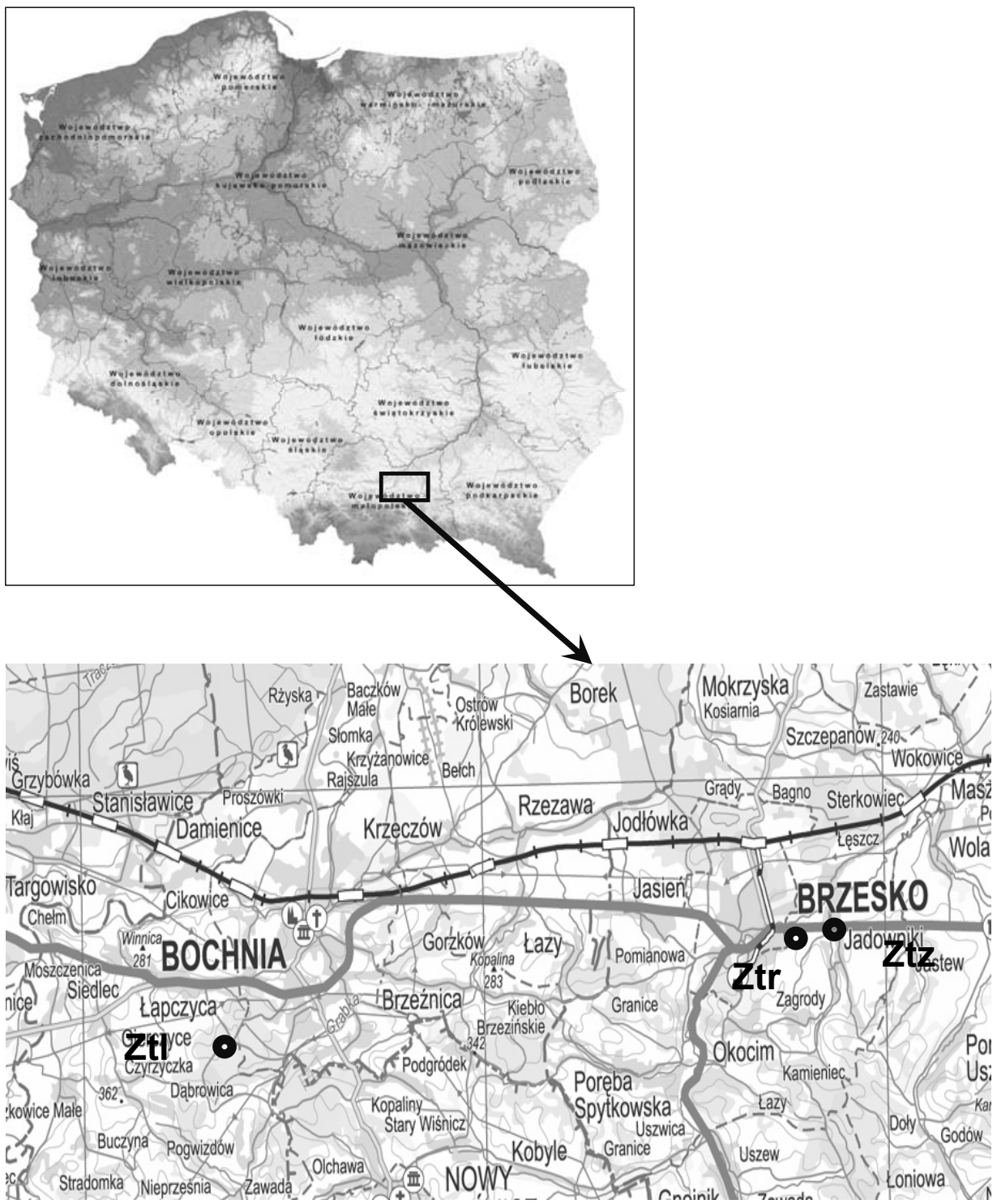

Explanations: Ztr - a catchment area with typical agricultural characteristics, $\mathbf{Z t z}$ - a catchment area with typical settlement and agricultural characteristics, $\mathbf{Z t l}$ - a catchment area with typical forest characteristics.

FIGURE 1. The location of the research sites 
land $(81 \%)$ which is characterized as a good quality, grasslands occur in a direct vicinity of water streams, and they are occupying circa $7 \%$ of the area, orchards are present sporadically $(5 \%)$, in which apples are prevailing. The forest area $(4 \%)$ is limited to the small clusters of trees located mainly in vicinity of the main stream source. In the catchment area there is no high density housing. In south-eastern part single households and homesteads are located. However, they are separated from the surface water by the plant consolidation belt (Fig. 2).

The prevalent part of settlementagricultural catchment area is occupied by arable lands (59\%). Grasslands which are present in a direct neighbourhood of the streams are occupying ca $8 \%$, orchards $4 \%$, and the forest area, located in southern part, comprises $19 \%$ of the area. Agriculture in catchment area has a typical extensive character, with small fragmented field and at present mostly abandoned. The cultivated arable lands are used for growing grain crops. The distribution of gradients of the discussed catchment area indicates on a clear superiority $(37.68 \%)$ of the terrain with a slope in the range from 5 to do $10 \%$. In the catchment area there is a large number of building developments. From the central part, towards northern direction, the belt of high density rural housing is running. In southern-western part of the catchment area there is, the second, what to the size, settlement of the detached houses. In the analysed area, there are located also single households as well as rural homesteads. In the catchment area about 320 agricultural farms is situated in which ca 1590 inhabitants live, what gives an average population density of 265 persons $/ \mathrm{km}^{2}$. Unfortunately this terrain, apart from the water-supply system, does not possess the sewerage

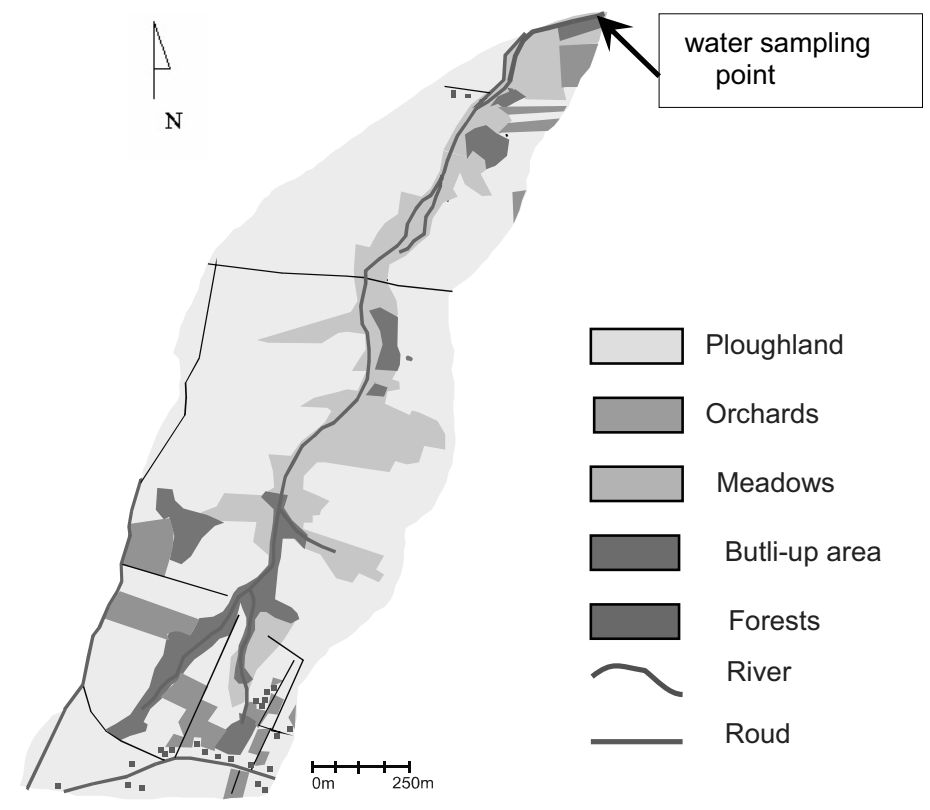

FIGURE 2. Map the catchment area with typical agricultural characteristics 
network. The homesteads are equipped with the wastewater tanks, without drainage (often wrongly sealed) and only few have household sewage treatment plants. (Fig. 3).

The distribution of gradients of the forest catchment area clearly indicates on the superiority of the land $(47.40 \%)$ with the slopes in the range from 5 to $10 \%$. The catchment area is covered in $75 \%$ by forest with dominant pine species. The arable lands take up $13 \%$; meadows and pasture $7 \%$; orchards occupy $3 \%$ of the catchment area and occur in summit parcels.
The urbanized areas are limited exclusively to several households located in neighbourhood of agricultural land, and do not have a direct contact with the main stream of the catchment area (Fig. 4).

The field studies were conducted from November 2005 to October 2007. Reaction $(\mathrm{pH})$, conductivity and dissolved oxygen were determined by equipment from the Elmetron Company. Nitrates, nitrites, ammonia, and phosphates were determined by the flow method of colorimetric analysis, and sulphates were detonated by a gravimetric analysis

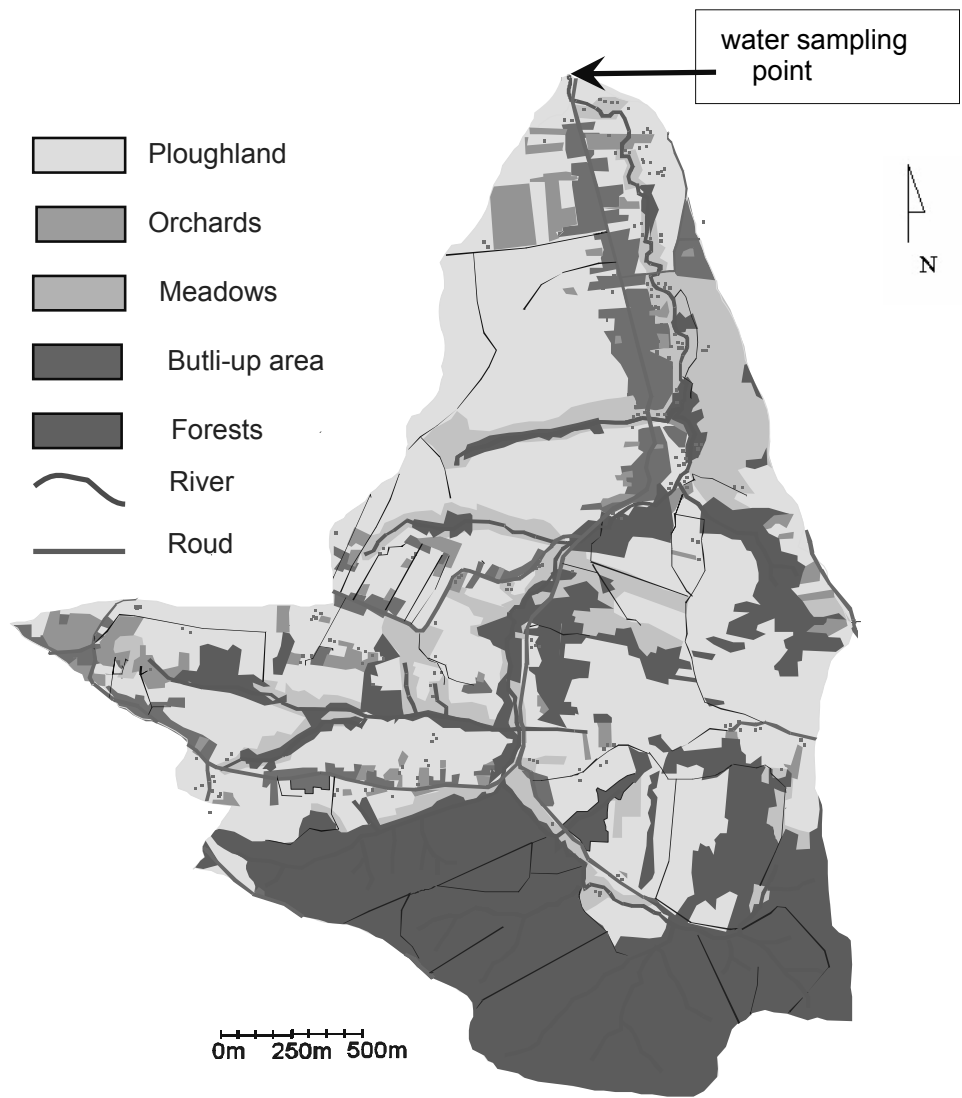

FIGURE 3. Map the catchment area with typical settlement and agricultural characteristics 


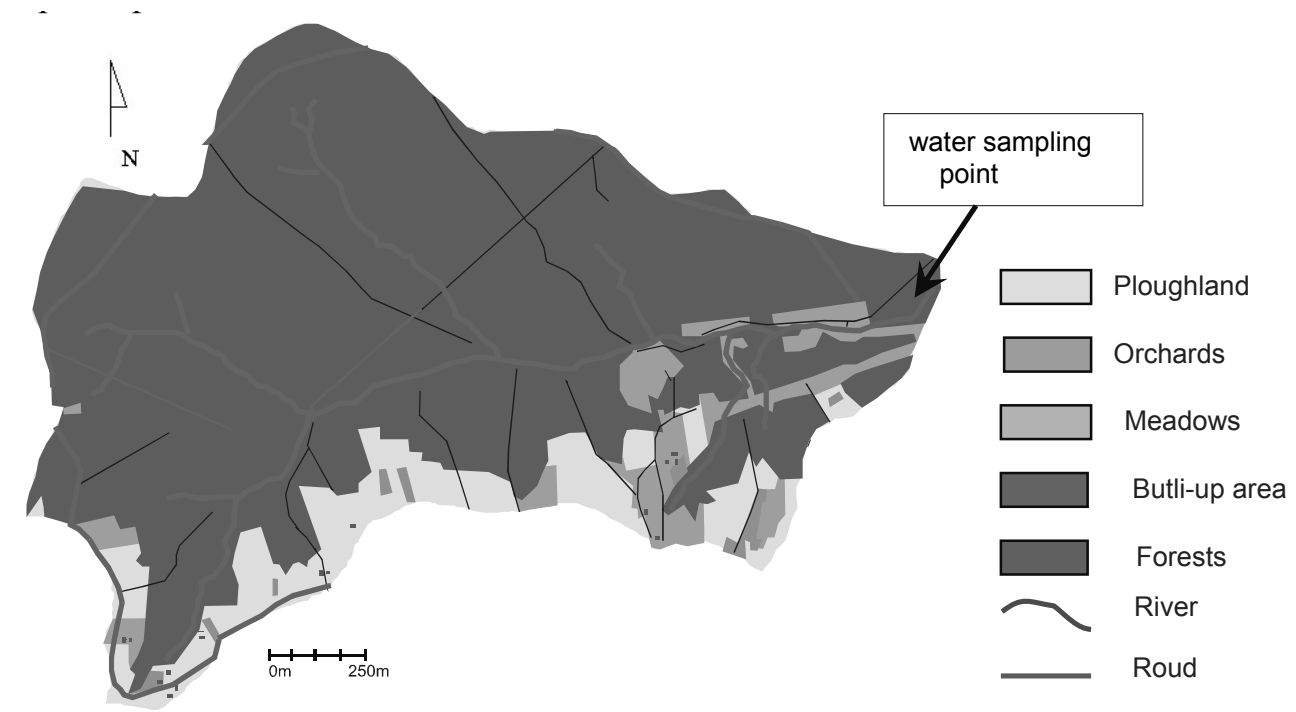

FIGURE 4. Map the catchment area with typical forest characteristics

(precipitation). Calcium and magnesium were analysed by an atomic absorption spectrophotometer of Unicam Solar M6 (Hermanowicz et al. 1999).

Based on results obtained by the direct method, the quality of the water was assessed and classified according to regulations established by the Minister of the Environment (Official Journal No 32 pos. 284 from March 1st 2004), for which the limiting values of investigated surface water quality indicators, for respective classes, are shown in at the Table 1.

\section{RESULTS AND DISCUSSION}

The results obtained during studies which concerned selected concentrations of the quality indicators of water flowing from wisely utilised land indicate a significant difference.

The mean values from the investigated period were in the range: for nitrates
$2.63-6.77 \mathrm{mg} \cdot \mathrm{dm}^{-3}$, nitrites $0.04-0.27$ $\mathrm{mg} \cdot \mathrm{dm}^{-3}$, ammonia $0.07-3.00 \mathrm{mg} \cdot \mathrm{dm}^{-3}$, phosphates $0.08-1.23 \mathrm{mg} \cdot \mathrm{dm}^{-3}$, sulphates $43.36-59.49 \mathrm{mg} \cdot \mathrm{dm}^{-3}$, chlorides $20.87-$ $-27.56 \mathrm{mg} \cdot \mathrm{dm}^{-3}$, calcium $19.07-130.37$ $\mathrm{mg} \cdot \mathrm{dm}^{-3}$, magnesium 9.02-18.95 $\mathrm{mg} \cdot \mathrm{dm}^{-3}$, dissolved oxygen $7.74-8.16$ $\mathrm{mg} \cdot \mathrm{dm}^{-3}$, conductivity $334.83-642.29$ $\mu \mathrm{S} \cdot \mathrm{cm}^{-1}$, reaction 7.58-7.99 phi.

The concentrations of nitrates, nitrites, ammonium and phosphate were characterised by the highest variability. The smallest coefficient of variability was recorded in the case of reaction and dissolved oxygen (Tab. 2).

Relying on the direct quality assessment of single water samples collected in the period of 24 dates (Tab. 3 ) one can conclude that only water in the streams located in forested terrain can qualify to the 1 st quality class. It was shown that the most polluted water was in streams situated in the agricultural-rural settlement areas, which most frequently were classified in the 5 th quality class. 
TABLE 1 . The limiting values of investigated surface water quality indicators for respective classes

\begin{tabular}{|l|c|c|c|c|c|c|}
\hline \multirow{2}{*}{ Water quality indicator } & \multirow{2}{*}{ Units } & \multicolumn{5}{|c|}{ The limiting values in classes } \\
\cline { 3 - 7 } & & I & II & III & IV & V \\
\hline Reaction & $\mathrm{pH}$ & $6.5-8.5$ & $6.0-8.5$ & $6.0-9.0$ & $5.5-9.0$ & $<5.5 ;>9.0$ \\
\hline Dissolved oxygen & $\mathrm{mg} \cdot \mathrm{dm}^{-3}$ & 7 & 6 & 5 & 4 & $>4$ \\
\hline Ammonia & $\mathrm{mg} \cdot \mathrm{dm}^{-3}$ & 0.5 & 1 & 2 & 4 & $>4$ \\
\hline Nitrite V & $\mathrm{mg} \cdot \mathrm{dm}^{-3}$ & 5 & 15 & 25 & 50 & $>50$ \\
\hline Nitrite III & $\mathrm{mg} \cdot \mathrm{dm}^{-3}$ & 0.03 & 0.1 & 0.5 & 1.0 & $>1.0$ \\
\hline Phosphate & $\mathrm{mg} \cdot \mathrm{dm}^{-3}$ & 0.2 & 0.4 & 0.7 & 1.0 & $>1.0$ \\
\hline Conductivity & $\mu \mathrm{S} \cdot \mathrm{cm}^{-1}$ & 500 & 1000 & 1500 & 2000 & $>2000$ \\
\hline Sulphate & $\mathrm{mg} \cdot \mathrm{dm}^{-3}$ & 100 & 150 & 250 & 300 & $>300$ \\
\hline Chlorides & $\mathrm{mg} \cdot \mathrm{dm}^{-3}$ & 100 & 200 & 300 & 400 & $>400$ \\
\hline Calcium & $\mathrm{mg} \cdot \mathrm{dm}^{-3}$ & 50 & 100 & 200 & 400 & $>400$ \\
\hline Magnesium & $\mathrm{mg} \cdot \mathrm{dm}^{-3}$ & 25 & 50 & 100 & 200 & $>200$ \\
\hline
\end{tabular}

TABLE 2. The values of selected quality indicators of water flowing from the following land areas: (1) a typical agricultural area, (2) rural settlements and agricultural land, (3) forest land

\begin{tabular}{|c|c|c|c|c|c|c|c|}
\hline \multicolumn{2}{|c|}{ The quality indicator } & Site & Minimum & Maximum & Mean & $\begin{array}{l}\text { Standard } \\
\text { Deviation }\end{array}$ & $\begin{array}{l}\text { Variability } \\
\text { coefficient }\end{array}$ \\
\hline \multicolumn{2}{|r|}{1} & 2 & 3 & 4 & 5 & 6 & 7 \\
\hline \multirow{3}{*}{$\mathrm{NO}_{3}^{-}$} & \multirow{3}{*}{$\mathrm{mg} \cdot \mathrm{dm}^{-3}$} & 1 & 0.145 & 10.397 & 4.21 & 2.85 & 0.68 \\
\hline & & 2 & 0.934 & 11.487 & 6.77 & 3.02 & 0.45 \\
\hline & & 3 & 0.124 & 9.024 & 2.63 & 2.80 & 1.06 \\
\hline \multirow{3}{*}{$\mathrm{NO}_{2}^{-}$} & \multirow{3}{*}{$\mathrm{mg} \cdot \mathrm{dm}^{-3}$} & 1 & 0.020 & 0.404 & 0.14 & 0.11 & 0.78 \\
\hline & & 2 & 0,050 & 0.811 & 0.27 & 0.23 & 0.85 \\
\hline & & 3 & 0,003 & 0.146 & 0.04 & 0.04 & 1.00 \\
\hline \multirow{3}{*}{$\mathrm{NH}_{4}^{+}$} & \multirow{3}{*}{$\mathrm{mg} \cdot \mathrm{dm}^{-3}$} & 1 & 0.113 & 9.169 & 3.00 & 2.94 & 0.98 \\
\hline & & 2 & 0.310 & 5.698 & 1.86 & 1.31 & 0.54 \\
\hline & & 3 & 0.008 & 0.189 & 0.07 & 0.05 & 0.71 \\
\hline \multirow{3}{*}{$\mathrm{PO}_{4}{ }^{3-}$} & \multirow{3}{*}{$\mathrm{mg} \cdot \mathrm{dm}^{-3}$} & 1 & 0.148 & 0.692 & 0.38 & 0.13 & 0.34 \\
\hline & & 2 & 0.013 & 2.726 & 1.23 & 0.79 & 0.64 \\
\hline & & 3 & 0.003 & 0.412 & 0.08 & 0.10 & 1.25 \\
\hline \multirow{3}{*}{$\mathrm{SO}_{4}^{2-}$} & \multirow{3}{*}{$\mathrm{mg} \cdot \mathrm{dm}^{-3}$} & 1 & 31.52 & 91.34 & 56.27 & 16.18 & 0.28 \\
\hline & & 2 & 45.70 & 81.50 & 59.49 & 9.45 & 0.15 \\
\hline & & 3 & 23.90 & 64.18 & 43.36 & 9.43 & 0.21 \\
\hline \multirow{3}{*}{$\mathrm{Cl}^{-}$} & \multirow{3}{*}{$\mathrm{mg} \cdot \mathrm{dm}^{-3}$} & 1 & 21.93 & 39.27 & 27.16 & 4.57 & 0.16 \\
\hline & & 2 & 22.5 & 33.4 & 27.56 & 2.92 & 0.10 \\
\hline & & 3 & 12.00 & 30.09 & 20.87 & 4.23 & 0.20 \\
\hline
\end{tabular}


Table 2 cont.

\begin{tabular}{|c|c|c|c|c|c|c|c|}
\hline & 1 & 2 & 3 & 4 & 5 & 6 & 7 \\
\hline \multirow{3}{*}{$\mathrm{Ca}^{+}$} & \multirow{3}{*}{$\mathrm{mg} \cdot \mathrm{dm}^{-3}$} & 1 & 85.6 & 170.0 & 130.37 & 25.41 & 0.19 \\
\hline & & 2 & 76.6 & 119.9 & 97.89 & 11.55 & 0.11 \\
\hline & & 3 & 3.5 & 34.3 & 19.07 & 6.90 & 0.36 \\
\hline \multirow{3}{*}{$\mathrm{Mg}^{+}$} & \multirow{3}{*}{$\mathrm{mg} \cdot \mathrm{dm}^{-3}$} & 1 & 8.2 & 32.9 & 18.79 & 6.96 & 0.37 \\
\hline & & 2 & 9.5 & 33.7 & 18.95 & 6.98 & 0.37 \\
\hline & & 3 & 4.5 & 12.6 & 9.02 & 2.10 & 0.22 \\
\hline \multirow{3}{*}{$\begin{array}{l}\text { Dis- } \\
\text { solved } \\
\text { oxygen }\end{array}$} & \multirow{3}{*}{$\mathrm{mg} \cdot \mathrm{dm}^{-3}$} & 1 & 6.12 & 9.02 & 7.74 & 0.77 & 0.10 \\
\hline & & 2 & 6.56 & 9.33 & 7.96 & 0.76 & 0.09 \\
\hline & & 3 & 7.14 & 9.31 & 8.16 & 0.60 & 0.07 \\
\hline \multirow{3}{*}{$\begin{array}{l}\text { Con- } \\
\text { ducti- } \\
\text { vity }\end{array}$} & \multirow{3}{*}{$\mu \mathrm{S} \cdot \mathrm{cm}^{-1}$} & 1 & 428 & 742 & 642.29 & 88.50 & 0.14 \\
\hline & & 2 & 391 & 692 & 587.21 & 85.59 & 0.14 \\
\hline & & 3 & 216 & 435 & 334.83 & 59.65 & 0.18 \\
\hline \multirow{3}{*}{$\begin{array}{l}\text { Re- } \\
\text { action }\end{array}$} & \multirow{3}{*}{$\mathrm{pH}$} & 1 & 7.38 & 8.46 & 7.87 & 0.28 & 0.03 \\
\hline & & 2 & 7.41 & 8.46 & 7.99 & 0.25 & 0.03 \\
\hline & & 3 & 6.91 & 8.18 & 7.58 & 0.28 & 0.04 \\
\hline
\end{tabular}

TABLE 3. Water sample dimensions in the investigated streams, in particular purity classes, established by a direct method

\begin{tabular}{|c|c|c|c|c|c|c|c|c|c|c|c|}
\hline \multirow{3}{*}{ Site } & \multirow{3}{*}{$\begin{array}{l}\text { The } \\
\text { number } \\
\text { of the } \\
\text { sampling } \\
\text { collection } \\
\text { dates }\end{array}$} & \multicolumn{10}{|c|}{ Water quality classes } \\
\hline & & \multicolumn{2}{|c|}{ I } & \multicolumn{2}{|c|}{ II } & \multicolumn{2}{|c|}{ III } & \multicolumn{2}{|c|}{ IV } & \multicolumn{2}{|c|}{ V } \\
\hline & & $\mathrm{n}$ & $\%$ & $\mathrm{n}$ & $\%$ & $\mathrm{n}$ & $\%$ & $\mathrm{n}$ & $\%$ & $\mathrm{n}$ & $\%$ \\
\hline 1 & 24 & 0 & 0 & 0 & 0 & 12 & 50 & 3 & 12.5 & 9 & 37.5 \\
\hline 2 & 24 & 0 & 0 & 0 & 0 & 5 & 20.8 & 6 & 25 & 13 & 54.2 \\
\hline 3 & 24 & 11 & 45.8 & 10 & 41.7 & 3 & 12.5 & 0 & 0 & 0 & 0 \\
\hline
\end{tabular}

Explanations: 1 - water flowing from a typical agricultural area, 2 - water flowing from agricultural and rural settlement areas, 3 - water flowing from forested land.

For water flowing from a class (50\%), and phosphates to the 2nd microcatchment area which was used class (50\%) and 3rd class $(41.7 \%)$.

as a typical agricultural area (Fig. 5), Moreover, categorisation of water biogenic compounds played the greatest flowing from a typical agricultural role in lowering the water quality: area to the 3rd class was decided by ammonium most frequently decreased calcium concentrations $(83.3 \%)$. Water the water quality to the 5 th class $(37.5 \%$ was categorised in the 2 nd class by the of determinations), nitrites to the 3rd presence of nitrates, magnesium and conductivity. The remaining analysed 


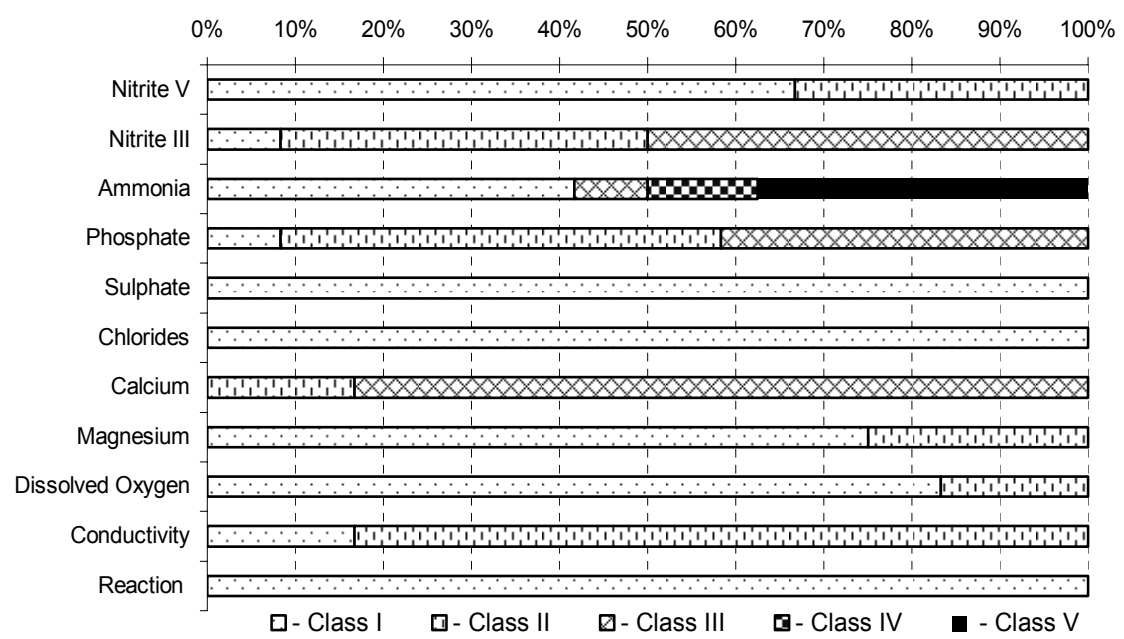

FIGURE 5. Distribution frequency (\%) of quality indicator values of water flowing from a catchment area used as typical agricultural land

indicators (chlorides, sulphates, and reaction) placed the water of the studied streams in the 1st class.

With regard to the nitrate concentrations, it has been found that most frequently the water flowing from rural settlements and agricultural areas (Fig. 6) qualified to the 2nd class ( $75 \%$ determinations). Nitrites more often decreased water quality to the 3rd class (54.3\%). Ammonia lowered the quality of water flowing from rural settlements and agricultural areas more often to the 3 rd class $(50 \%)$ and 4 th class (29.9\%), and even sometimes to the 5th class $(8.3 \%)$. Phosphate proved to be a compound which, when concentrated in water flowing from rural settlements and agricultural areas, often qualified this water to the 5 th class $(54.1 \%)$. As for calcium concentrations, the water qualified to the 2 nd and 3 rd class $(50 \%$ respectively). It has been affirmed that neither chlorides nor sulphates lowered the quality of water under investigation. Conductivity classified the water flowing from the studied areas most often to the 2nd class, oxygenation to the 1st class, and reaction always to the 1st class.

Water flowing from a wooded catchment area, for most of the analysed indicators, was characterised as very good quality (Fig. 7). Only phosphates in $50 \%$ of the conducted determinations decreased the water quality to the 2nd class. It has been found that several times nitrates $(20.8 \%$ determinations $)$ and nitrites $(29.9 \%)$ qualified water flowing from the forested area to the 2nd class, and in the case of nitrite concentrations, several times to the $3 \mathrm{rd}$ class $(20.8 \%$ determinations). As for the remaining indicators $\left(\mathrm{NH}_{4}{ }^{+}, \mathrm{SO}_{4}{ }^{2-}, \mathrm{Cl}^{-}, \mathrm{Ca}^{+}, \mathrm{Mg}^{+}\right.$, $\mathrm{Na}^{+}, \mathrm{K}^{+}$, dissolved oxygen, conductivity, $\mathrm{pH}$ ), the water flowing from the forest terrain, apart from incidental cases, was qualified to the 1 st class.

The quality analysis of water flowing through variously used areas of land during the study period, assessed by the direct method (with a frequency of $90 \%$ ), proved that in regards to the 


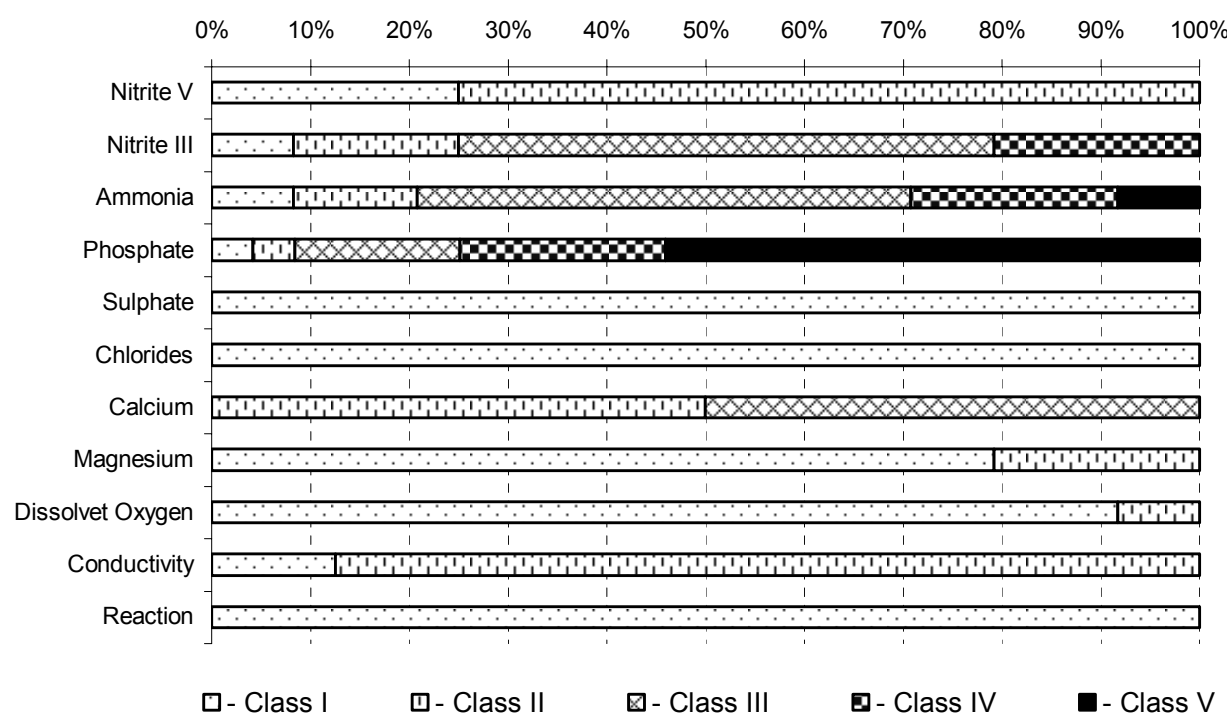

FIGURE 6. Distribution frequency (\%) of the quality indicator values of water flowing from a catchment area used as a rural settlement and agricultural land

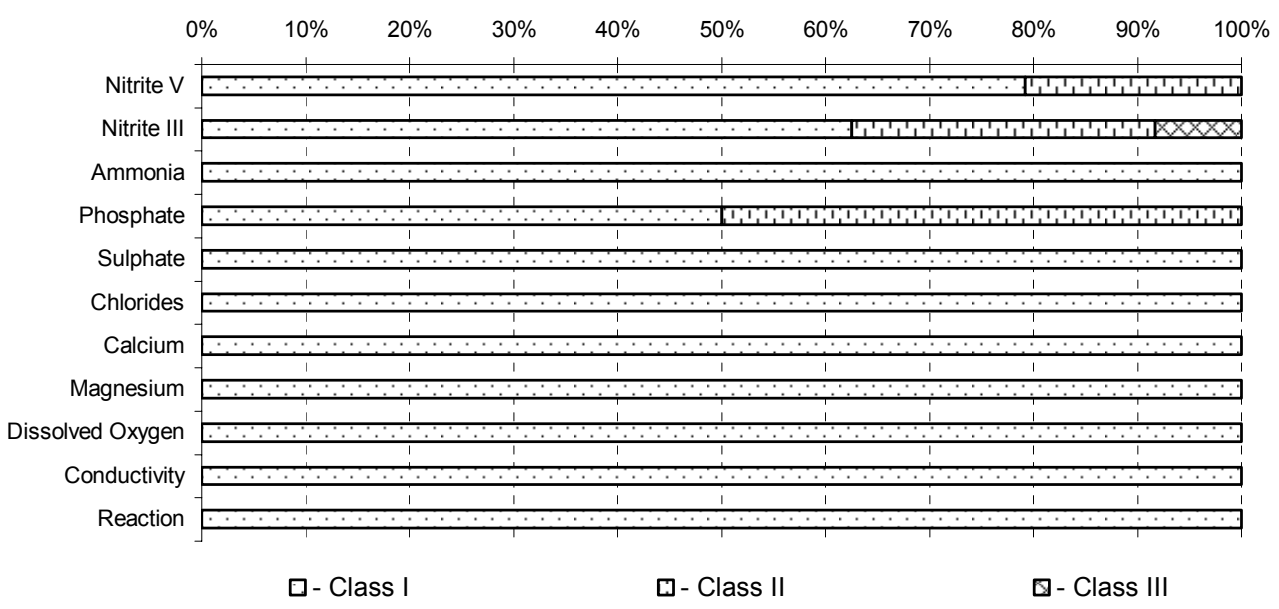

FIGURE 7. Distribution frequency (\%) of the quality indicator values of water flowing from a catchment area used as forest 
ammonia concentration, water flowing from a typical agricultural catchment area should be ranked as poor quality (Figs. 5-7). In the case of water flowing from rural settlements and agricultural areas, the phosphate concentrations were decisive for the classification of the water, which was characterised as being of poor quality.

It was established that in the case of water flowing from a typical agricultural catchment area, 3 indicators qualified the water to the 1 st class, 4 to the 2 nd class, 3 to the 3 rd class, 0 to the 4 th class and 1 indicator to the 5 th class.

In water flowing from a catchment area utilised as rural settlement and agricultural land, 4 indicators qualify it to the 1 st class, 3 to the 2 nd class, 1 to the 3 rd class, 2 to the 4th class and 1 to the 5th class. In water flowing from a forested catchment area, 8 indicators allow it to be ranked in the 1st class and 3 in the 2 nd class. The tendency for a larger decrease in the water quality of foothill streams in rural settlements and agricultural areas than in the case of wooded areas is confirmed by research conducted by Pijanowski and Kanownik (1997). This statement, based on studies conducted by Rajda, Natkaniec (2000) and Koc et al. (1997), Misztal (1998), Zbierska and Szoszkiewicz (1992) is justified by the impact of agricultural land use, the vicinity of farms, and the lack of sewage systems in compacted built-up areas or scattered housing in which the often encountered practice is the delivery of domestic sewage directly into the streams. An unfavourable impact is also caused by the presence in farms of leaky sewage tanks (without outflow), collecting tanks for liquid manure that are not tight enough, and inappropriate manure pits.

\section{CONCLUSIONS}

1. On the basis of a direct quality assessment of single water samples it was found that only water flowing from forest areas can qualify to the $1 \mathrm{st}$ cleanness class. It turned out that the most polluted was water from rural settlements and agricultural areas, which qualified most frequently to the 5 th class.

2. The quality analysis by a direct method proved that the indicators which lowered the water quality the most were biogenic compounds and calcium, and the least were sulphates, chlorides and reaction.

3. It has been shown that in the case of small water streams situated in rural settlements and agricultural areas, the water quality was lowered most by phosphates (to the 5th class) and ammonia (to the 4th class). In water flowing from a typical agricultural microcatchment area, its quality was decreased the most by ammonium (to the 5th class). Water flowing from forest catchment areas was characterised by decidedly the best quality.

4. The water quality of streams which drain foothill microcatchment areas was decided chiefly by phosphates, nitrates and nitrites. 


\section{REFERENCES}

HERMANOWICZ W., DOJLIDO J., DOŻAŃSKA W., KOZIOROWSKI B., ZERBE J. 1999: Fizyczno-chemiczne badania wody i ścieków. [Physical and chemical investigations of water and sewages], Publisher Arkady, Warszawa.

KOC J., PROCYK Z., SZYMCZYK S. 1997: Czynniki kształtujące jakość wód powierzchniowych obszarów wiejskich. [The factors which are shaping the surface water quality of the rural areas. Materials from Seminar: Water as a conditional factor of multifunctional and sustainable development of village and agriculture], Falenty, 222-229.

KONDRACKI J. 2002: Geografia regionalna Polski. [Regional geography]. PWN, Warszawa.

MISZTAL A. 1998. Gospodarstwa rolne potencjalnym źródłem zanieczyszczenia gleby i wody. [Agricultural farms as a potential pollution source of the soil and water]. The materials from the scientific conference on a good practice in agricultural production. Puławy, 375-385.

PIJANOWSKI Z., KANOWNIK W. 1997: Zmienność stężeń wybranych substancji chemicznych w wodach powierzchniowych przepływających przez tereny wiejskie o różnym zagospodarowaniu. [The concentration variability of selected chemical substances in surface waters which is flowing through the rural areas of different land management]. Annals AR Poznań, Land Drainage and EnvironmentalEngineering 19.2, 347-358. [Engl. summ.].

RAJDA W., NATKANIEC J. 2000: Fizykochemiczne cechy wód powierzchnio- wych mikrozlewni rolniczej i osadniczej. [Physical and chemical features of the surface water of agricultural and settlement microcatchment]. Scientific Brochure Series, AR Cracow, Environmental Engineering 20, 5-13 [Engl. summ.].

ZBIERSKA J., SZOSZKIEWICZ K. 1992: Water problems of Poland. Materials from Seminar IAAS "Civil engineering and water management at university and in practice". Vienna/Poznań, 64-69.

Streszczenie: Wplyw użytkowania terenu na jakość wód mikrozlewni podgórskich. W pracy dokonano porównania wpływu sposobu użytkowania terenu na jakość wód odwadniających je cieków wodnych. W tym celu wytypowano trzy mikrozlewnie zlokalizowane na terenach użytkowanych rolniczo, osadniczo-rolniczo i leśnie, z których próbki wody poddano analizie fizykochemicznej, oznaczając azotany, azotyny, amoniak, fosforany, siarczany, chlorki, wapń, magnez, tlen rozpuszczony, odczyn i przewodność elektryczną właściwą. Badania prowadzono w okresie dwóch lat hydrologicznych 2006 i 2007. Analiza zebranego materiału pozwoliła stwierdzić, że na jakość wód cieków wodnych istotny wpływ wywiera sposób użytkowania terenu, który odwadniają. Najbardziej negatywnie na jakość wody oddziaływają tereny osadniczo-rolnicze, a następnie użytkowane typowo rolniczo. Na podstawie bezpośredniej oceny jakości pojedynczych próbek wody stwierdzono, że tylko wody terenów leśnych mogłyby być zakwalifikowane do I klasy czystości.

\section{Authors' address:}

Andrzej Misztal, Marcin Kuczera

Wydział Inżynierii Środowiska i Geodezji,

Uniwersytet Rolniczy im. Hugona Kołłątaja w Krakowie

30-059 Kraków, al. Mickiewicza 24/28, Poland

e-mail:rmmiszta@cyf-kr.edu.pl 